\title{
Lanice conchilega structures carbon flows in soft-bottom intertidal areas
}

\author{
Bart De Smet $^{1, *}$, Dick van Oevelen ${ }^{2}$, Magda Vincx ${ }^{1}$, Jan Vanaverbeke ${ }^{3}$, \\ Karline Soetaert ${ }^{2}$

\begin{abstract}
${ }^{1}$ Department of Biology, Marine Biology Research Group, Ghent University, Krijgslaan 281/S8, 9000 Ghent, Belgium PO Box 140, 4400 AC Yerseke, The Netherlands
\end{abstract} \\ ${ }^{2}$ NIOZ Royal Netherlands Institute for Sea Research, Department of Estuarine and Delta Systems, and Utrecht University, \\ ${ }^{3}$ Royal Belgian Institute of Natural Sciences, Operational Directorate Natural Environment (OD Nature), Marine Ecology \\ and Management, Gulledelle 100, 1200 Brussels, Belgium
}

\begin{abstract}
Biogenic reefs constructed by the tube-building ecosystem engineer Lanice conchilega (Terrebilidae, Polychaeta) have profound structuring impacts on the benthic environment in that they alter the biogeochemical and physical properties of the sediment. This study provides new insights into the functioning and effects on food webs of $L$. conchilega reefs in intertidal sediments using linear inverse models to quantify the carbon flows in the food webs in the presence and absence of the tubeworm. The inverse food web models were based on an empirical dataset from 2 study sites, which provided biomass and stable isotope data, and information on general physiological constraints from the literature. Results of the model showed that the carbon input into reef food webs (mean $\pm \mathrm{SE} ; 191 \pm 50 \mathrm{mmol} \mathrm{C} \mathrm{m}^{-2} \mathrm{~d}^{-1}$ ) is ca. 40 times higher compared to bare

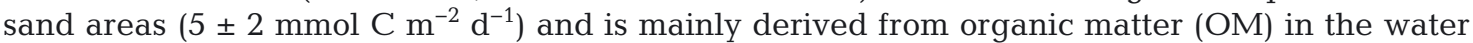
column. Most of the OM input towards these reefs is consumed by suspension-feeding macrofauna, particularly L. conchilega; however, the worm is not an important source of carbon for other macrofaunal organisms. The ratio of OM input to primary production indicates that the OM needs to be produced in an area at least 15 times larger than the reef area, demonstrating significant OM 'focussing' within the reef food web. The reef structures created by L. conchilega act as a trap for $\mathrm{OM}$, resulting in an overall higher macrofaunal biomass and much more diverse food webs than in the absence of the tubeworm.
\end{abstract}

KEY WORDS: Linear inverse model $\cdot$ Biogenic habitat $\cdot$ Food web $\cdot$ Network analysis $\cdot$ Stable isotopes $\cdot$ Lanice conchilega $\cdot$ Ecosystem engineering

\section{INTRODUCTION}

Ecosystem engineers are organisms that directly or indirectly modulate the availability of resources to other species by reshaping the landscape (Jones et al. 1994). Biogenic reefs constructed by ecosystem engineers are one of the most striking structures in softbottom intertidal areas (Holt et al. 1998). A prime example are the aggregations of the tubeworm Lanice conchilega (Polychaeta, Terebellidae), which can

\footnotetext{
*Corresponding author: badsmet.desmet@ugent.be
}

reach densities of up to several thousands of individuals per square meter (Van Hoey et al. 2006) and are called L. conchilega reefs (Rabaut et al. 2009). In Europe, where the largest populations of this tubedwelling polychaete are found, $L$. conchilega colonises a wide range of intertidal and subtidal sediments down to depths of approximately 1900 m (HartmannSchröder 1996). Large reefs are found in the Wadden Sea (Petersen \& Exo 1999) and in France, especially in the Bay of Mont Saint-Michel (Godet et al. 2008).

() The authors 2016. Open Access under Creative Commons by Attribution Licence. Use, distribution and reproduction are unrestricted. Authors and original publication must be credited. 
L. conchilega reefs have profound structuring impacts on the benthic environment in that they alter the biogeochemical (Forster \& Graf 1995, Braeckman et al. 2010) and physical (e.g. Degraer et al. 2008, Rabaut et al. 2009, Borsje et al. 2014) properties of the sediment. As a result, L. conchilega affects the community composition, abundance and species richness within the reef (Zühlke et al. 1998, Rabaut et al. 2007, 2013, Godet et al. 2008, Braeckman et al. 2011, De Smet et al. 2013). Moreover, intertidal $L$. conchilega reefs are important from a conservation point of view due to their central role in the link between benthic, pelagic and air-borne parts of the intertidal food web (De Smet et al. 2013, 2015a). Despite their structuring role on the meio- and macrofauna, these reefs seem to have a minor effect on the overall structure of the soft-bottom intertidal food web. Based on stable isotope analysis, the consumer community in the presence and absence of $L$. conchilega showed very similar isotopic niche widths, implying that consumers hardly change their diet when feeding in an L. conchilega reef (De Smet et al. $2015 b)$. Also, the stability of the food web in the presence of $L$. conchilega, as evaluated based on the density of species packing and hence the trophic redundancy, remained unaltered (De Smet et al. 2015b).

Whereas De Smet et al. (2015b) looked at qualitative aspects of the food web, another important aspect of food web research comprises the quantification of food web flows, which yields a more realistic approximation of complex food webs (De Ruiter et al. 1995, Woodward et al. 2005). The in situ quantification of food web flows is a labour-intensive task (Berlow et al. 2004), but the development of linear inverse modelling has been a big step forward in food web research. Linear inverse modelling is a data assimilation method allowing the integration of carbon processes (e.g. respiration), biomass and stable isotope data to quantify elemental flows in food webs (Vézina \& Platt 1988, van Oevelen et al. 2006, 2010). By merging a variety of traditional data types and currently underexploited data sources, linear inverse models (LIMs) are used to quantitatively reconstruct pathways in systems as small as single cells up to entire food webs. This feature makes LIMs an effective tool to bridge the gap between incomplete and uncertain empirical data on natural food webs and the analysis of food web structures (van Oevelen et al. 2010).

Although the effect of L. conchilega on food web topology appears to be limited (De Smet et al. 2015b), this has not been confirmed by a quantification of the carbon flows between the different compartments of an L. conchilega-dominated food web. Nevertheless, given the impact of $L$. conchilega on the biogeochemical and physical aspects of its environment and on the macrofaunal community, it can be expected to significantly alter the food web flows in intertidal ecosystems.

This study develops LIMs to present a comprehensive overview of carbon cycling and the dynamics of a soft-bottom intertidal food web in the presence and absence of ecosystem-engineered $L$. conchilega reefs, focussing on the macrofaunal part of the food web. A selection of network indices, representing the complex interactions between the compartments, is used to compare the different food web models. Moreover, in order to address temporal and spatial variation in the food web structure, 2 study sites and 2 seasons were taken into account.

\section{MATERIALS AND METHODS}

\section{Study site and food web structure}

The 2 study sites are located along the French coast of the English Channel and were selected because of their extensive and well-established intertidal Lanice conchilega reefs. The Bay of Mont Saint-Michel (BMSM) is a large-scale intertidal sand flat in the Normand-Breton Gulf $\left(48^{\circ} 39.70^{\prime} \mathrm{N}, \quad 01^{\circ} 37.41^{\prime} \mathrm{W}\right.$; Lower Normandy, France), while Boulogne-sur-Mer (henceforth, Boulogne) is a small soft-bottom intertidal area in the Nord-Pas de Calais region $\left(50^{\circ} 44.01^{\prime} \mathrm{N}, 01^{\circ} 35.15^{\prime} \mathrm{E}_{\text {; }}\right.$ Northern France) (Fig. 1). At both locations, an area dominated by an L. onchilega reef and a bare sediment area were chosen for reconstructing carbon flows within the macrofaunal part of the food web. A separate analysis was performed for 2 time periods, spring and autumn. Consequently, 8 different food webs were quantified.

This study focusses on the bentho-pelagic community of the soft-bottom intertidal food web, as described by De Smet et al. (2015a). The most abundant species, ranging from smaller polychaetes up to fish, were included as separate compartments interconnected by flows (Fig. 2 shows a simplified version of the complex overall food web used in this study). Sedimentary microphytobenthos and water-column derived phytoplankton constitute the inputs to the food webs; they are fed upon by detritus- and suspension-feeding macrofauna. Connections between the macrofaunal compartments were defined based on diet information from the literature; FishBase (Froese \& Pauly 2015) as well as results from stomach 


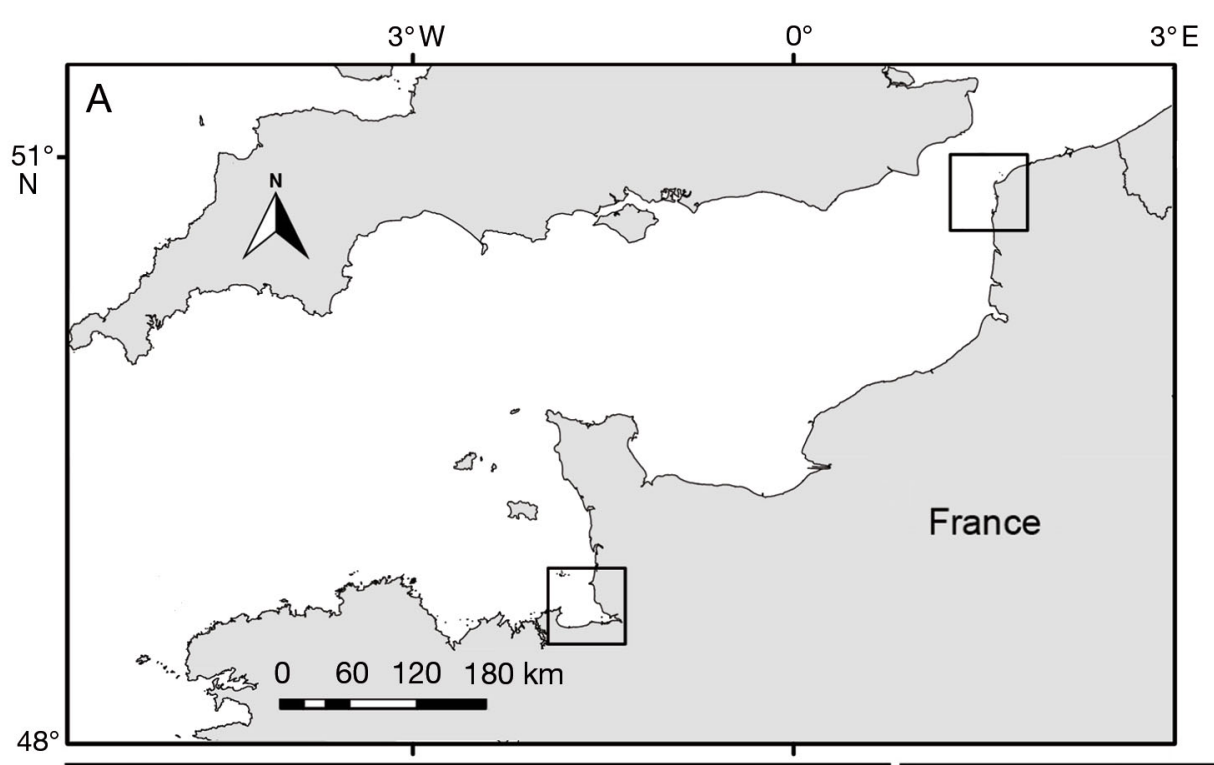

Fig. 1. The 2 study sites on the French side of the English Channel. (A) Boulogne-sur-Mer (Boulogne; upper square) and the Bay of Mont Saint-Michel (BMSM; lower square) and the Lanice conchilega reef in the intertidal area of (B) BMSM and (C) Boulogne

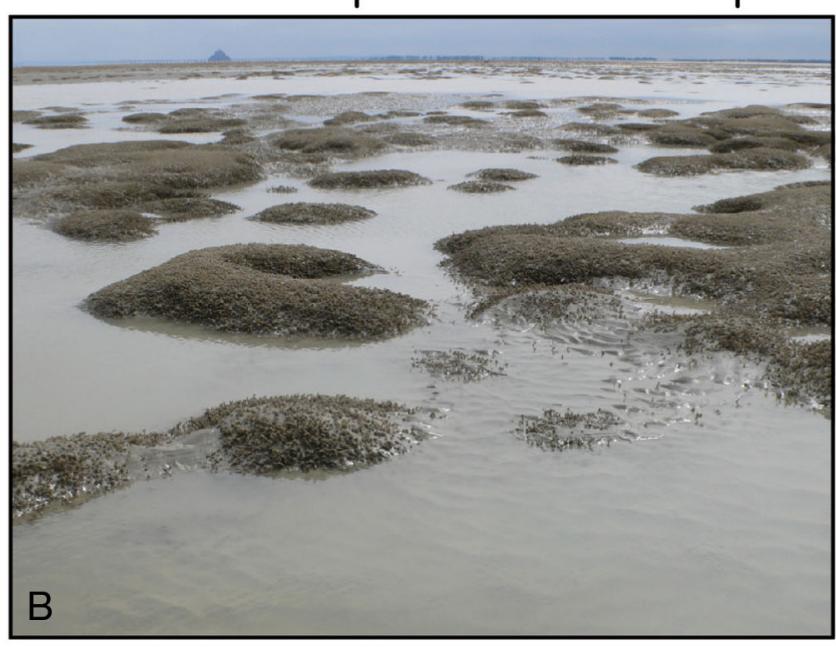

content analysis (P. Verhelst unpubl.) were used to define flows to and among fish species, while Fauchald \& Jumars (1979), De Smet et al. (2015b) and the World Register of Marine Species (WoRMS Editorial Board 2015) were used to define flows to and among all other macrofaunal compartments. Loss of carbon from the food webs includes macrofaunal mortality and faeces production, macrofaunal respiration, and predation due to animals not accounted for in the model (e.g. predation by wading birds and seals). The a priori defined compartments interconnected by flows constitute the overall topological food web model on which the linear inverse model for the 8 food webs is based (Fig. 2).

\section{Data availability}

Site-specific empirical data and literature data on carbon stocks and process rates were implemented in

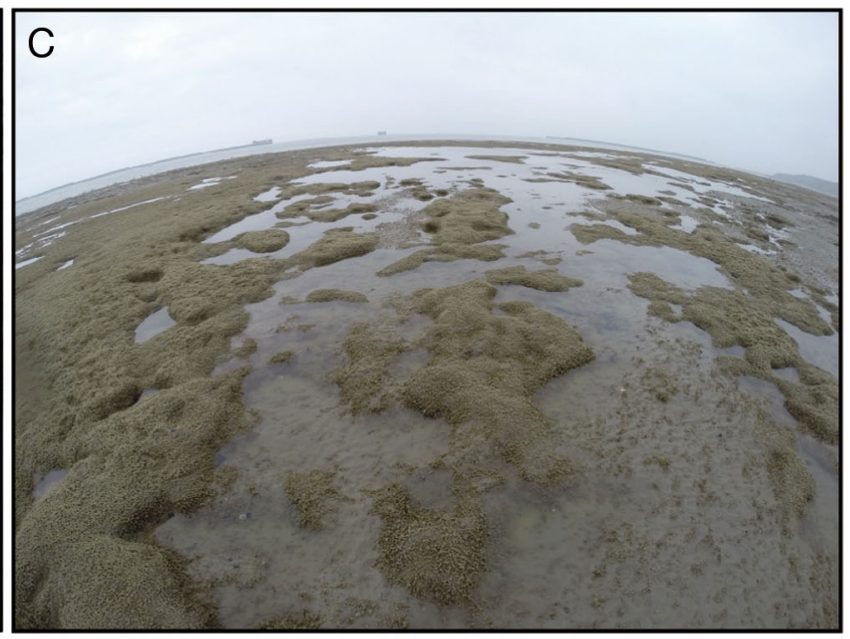

the food web model. The empirical data included biomasses and $\delta^{13} \mathrm{C}$ stable isotope signatures of primary food sources and consumer species. In order to further constrain the carbon flows in the food web, primary production rates, respiration rates, assimilation efficiencies and net growth efficiencies of macrofaunal compartments were taken from the literature.

\section{Empirical data}

At both locations, quantitative sampling of the primary food sources (microphytobenthos and phytoplankton) and the macro-, hyper- and epibenthic fauna inhabiting an L. conchilega reef area and a bare sand area took place in spring in 2012 (from March 7 to 13 in the BMSM and from March 22 to 25 in Boulogne) and in autumn in 2012 (from September 17 to 21 in BMSM and from October 15 to 18 in Boulogne). The carbon pool (in $\mathrm{mmol} \mathrm{C} \mathrm{m}^{-2}$ ) in the 


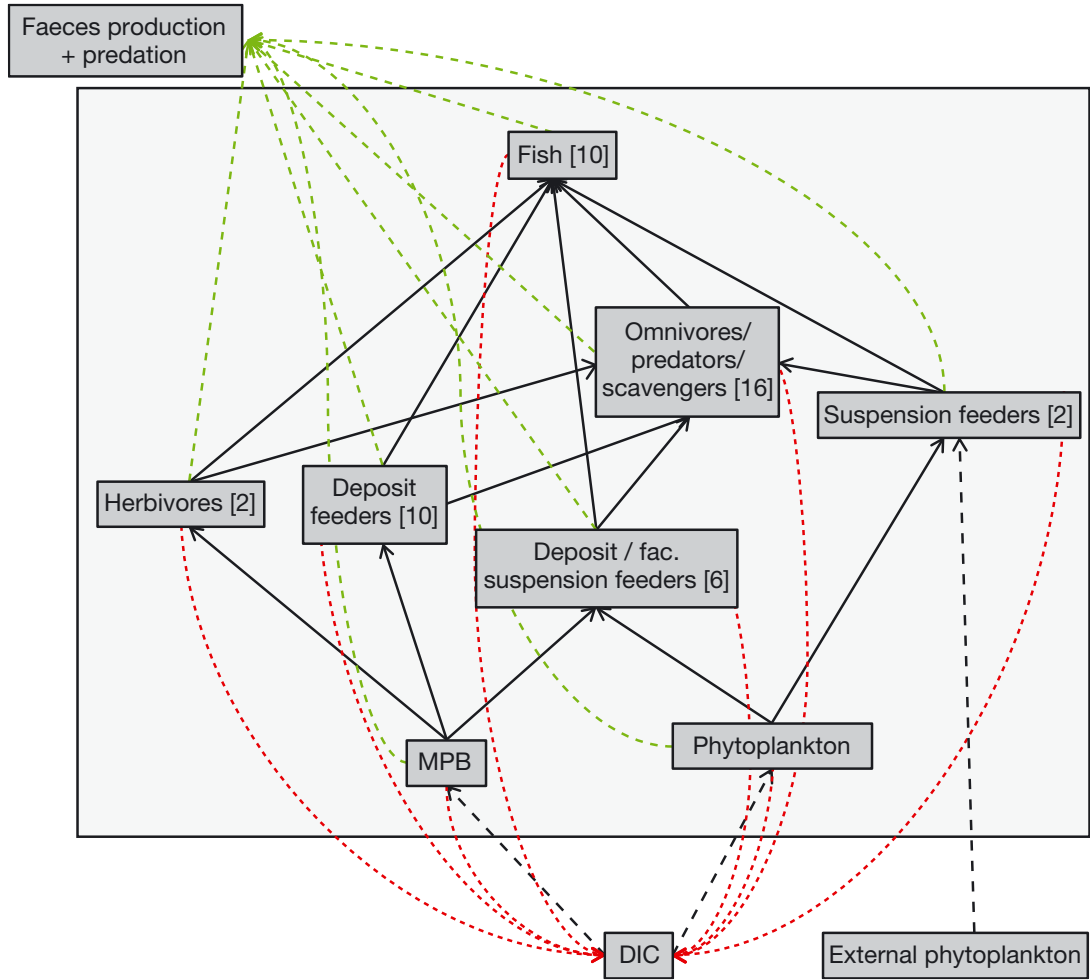

Fig. 2. Simplified schematic representation of the overall complex topological food web on which the linear inverse model (LIM) is based. Compartments inside the large box are included in the model, while compartments outside were not explicitly modelled. Links between the compartments (black solid arrows) were based on literature and stomach content analysis of fish. For simplicity, species were lumped in functional groups in the scheme; however, single species compartments were used in the model (the number of species included in each functional group is displayed in parentheses). Black dashed arrows represent the external input to the model, while red dashed arrows represent the loss of carbon from the food web as a result of respiration, and green dashed arrows the production of faeces + predation by animals not included in the model. $\mathrm{MPB}=$ microphytobenthos, $\mathrm{DIC}=$ dissolved inorganic carbon

microphytobenthos (MICPHY) and phytoplankton (PHYTOP) was calculated by converting the amount of chlorophyll a $(\mathrm{chl} a)$ to carbon equivalents, assuming a C:chl a ratio of 40 (Stephens et al. 1997), and subsequently to molar units. Macro-, hyper- and epibenthic organisms were collected, identified to species level and counted. Species that could not be distinguished with certainty were grouped at the genus level (see De Smet et al. 2015a for a detailed description of the sampling design and processing). Wet mass of the organisms was determined and subsequently converted to dry mass and carbon units (mmol C m${ }^{-2}$ ) by using taxon-specific conversion factors from Brey (2001) (Table S1 in the Supplement at www.int-res.com/articles/suppl/m552p047_supp.pdf). Stable isotope data $\left(\delta^{13} \mathrm{C}\right)$ were available for the primary food sources and the majority of the faunal species (De Smet et al. 2015b) (Table S2 in the Supple- ment). If the isotope value of a species was not available for a sampling area (reef and bare sand), a season (spring and autumn) or a location (BMSM and Boulogne), the isotope value of that species from another sampling area, season or location had to be assumed (Table S2). If isotope data for a species were completely lacking, the isotope values of a taxonomically related species were adopted (e.g. for bivalves: the $\delta^{13} \mathrm{C}$ value of Macoma balthica was adopted for Tellina tenuis), or the background isotope value of a ${ }^{13} \mathrm{C}$ pulsechase experiment, conducted for the site of Boulogne, was used (De Smet et al. 2016).

\section{Literature data}

Minimum and maximum bounds on the production rates of microphytobenthos per season for the BMSM were taken from gross primary production (GPP) measurements in the intertidal area of the BMSM (Davoult et al. 2009) (Table 1). As no literature data on the GPP of microphytobenthos for the intertidal area of Boulogne were available, the GPP in the BMSM was used for Boulogne (Table 1). Maximum bounds on the seasonal production rate of phytoplankton were obtained from GPP measurements in the Bay of MarennesOléron along the Atlantic coast of France (Struski \& Bacher 2006), a well-studied intertidal area based on LIMs (e.g. Pacella et al. 2013, Saint-Béat et al. 2014). The GPP values were assumed to be the same for the areas of the BMSM and Boulogne (Table 1), and since the primary production measured by Struski \& Bacher (2006) was largely the same in spring and autumn, a constant GPP was used for both seasons. The minimum and maximum respiration rates of the primary producers were set at 5 and $30 \%$ of the GPP respectively (Vézina \& Platt 1988) (Table 1).

Macrofaunal respiration was implemented as the sum of maintenance respiration and growth respiration (Soetaert \& van Oevelen 2009). Maintenance respiration was taken as $1 \%$ of the biomass per day for smaller macrofaunal organisms (Polychaeta, Isopoda, Mysida and Amphipoda) (Fenchel 1982, Nielsen et al. 1995) and $0.1 \%$ for larger invertebrates 
Table 1. Constraints imposed on processes implemented in the macrofaunal food webs. The minimum (lower boundary) and maximum (upper boundary) values are implemented as inequalities in the linear inverse model. Sources represent the literature from which the data was obtained

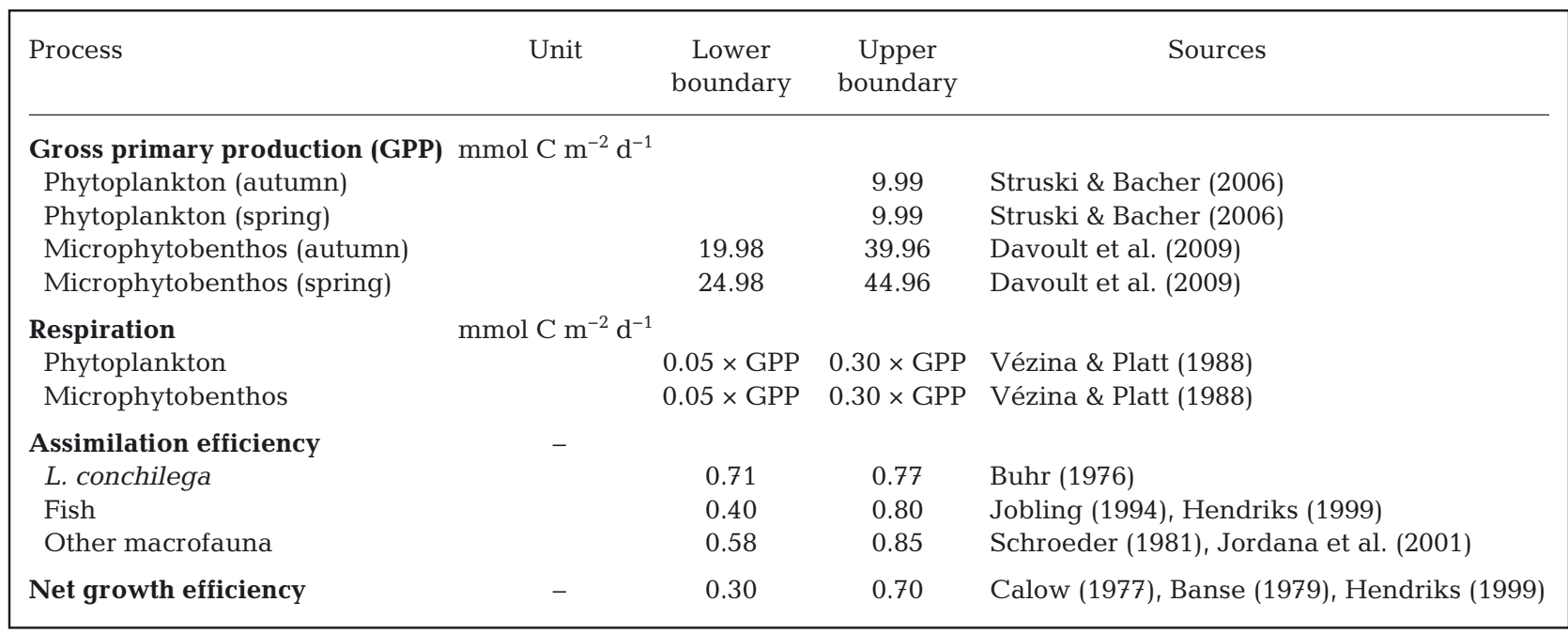

(Decapoda, Bivalvia and Cephalopoda) and fish (e.g. Hepher et al. 1983). Subsequently, the maintenance respiration was corrected for temperature with a temperature limitation factor (Tlim) based on a $Q_{10}$ of 2 (van Oevelen et al. 2012). The total respiration was estimated from biomass by using an allometric formula for shallow water organisms at a 15 to $20^{\circ} \mathrm{C}$ temperature range (Mahaut et al. 1995):

$$
r=0.017 . W^{-0.156}
$$

with $r$ being the biomass-specific respiration rate $\left(\mathrm{d}^{-1}\right)$ and $W$ the individual biomass $\left(\mathrm{mg} \mathrm{C}\right.$ ind $\left.^{-1}\right)$. The respiration rate $(R)$ of each species was calculated by multiplying its biomass with $r$ and converting it to carbon units $\left(\mathrm{mmol} \mathrm{C} \mathrm{m}^{-2}\right.$ ). The lower and upper boundaries of the respiration rate were set as $R / 2$ and $2 \times R$ respectively (van Oevelen et al. 2009).

The assimilation efficiency (AE) is the ratio of assimilation (= production + respiration) to consumption and is independent of body size (Banse 1979, Hendriks 1999). Lower and upper boundaries of the $\mathrm{AE}$ were between 71 and $77 \%$ for L. conchilega (Buhr 1976), between 40 and $80 \%$ for fish species (Jobling 1994, Hendriks 1999), and between 58 and $85 \%$ for all other macrofaunal organisms (Schroeder 1981, Jordana et al. 2001) (Table 1). Finally, the net growth efficiency (NGE) is the ratio of production (i.e. growth) to assimilation. The NGE is independent of body size, and lower and upper boundaries on the faunal NGE were set between 30 and $70 \%$ (Calow 1977, Banse 1979, Hendriks 1999) (Table 1).

\section{Linear inverse model formulation}

Based on the overall topological food web, an inverse model was developed. From the mathematical point of view, an inverse model contains data on carbon flows in the food web cast in matrix notation as a set of linear equality (1) and inequality equations (2):

$$
\begin{aligned}
& A \cdot \mathbf{x}=\mathbf{b} \\
& \mathbf{G} \cdot \mathbf{x} \geq \mathbf{h}
\end{aligned}
$$

in which $\mathbf{x}$ is a vector with $N$ unknown food web flows. Each row in matrix $\mathbf{A}$ is a mass balance or data point expressed as a linear combination of the food web flows, where the corresponding rate of change of a compartment (for mass balances) or numerical value (for data equalities) is given in vector $\mathbf{b}$. $\mathbf{h}$ is a vector containing values of biological constraints, and the constraint coefficients, signifying whether and how much a flow contributes to the constraint, are given in matrix $\mathbf{G}$ (Vézina \& Platt 1988). Quantitative, site-specific data (i.e. the biomass and $\delta^{13} \mathrm{C}$ values of the different compartments) were added to the model as equality equations. Absolute values of the lower and upper bounds of the literature data (production rates, assimilation efficiencies, net growth efficiencies and respiration rates) were added to the model as inequalities since they are used to constrain single flows or linear combinations of flows to biologically realistic values. The complete model 
consists of 727 flows, 48 mass balances (i.e. one for each compartment), 46 data equalities and 142 data inequalities.

As in the majority of LIMs, the food webs in this study are under-sampled and the number of equalities $(48+46)$ is insufficient to balance the number of unknown flows (727) (van Oevelen et al. 2010). Therefore, the LIM is under-determined and the matrix equations have an infinite number of solutions (van Oevelen et al. 2010). This problem can be solved in 3 ways: (1) upgrading literature data (i.e. data from other study sites that can be incorporated in the model as inequality constraints) in order to incorporate the data in the model as fixed equalities; (2) singling out one 'best' solution (i.e. food web structure) based on the assumption of parsimony or simplicity; or (3) quantifying uncertainty, i.e. using a likelihood approach which generates a large set of possible solutions, or determining flow ranges. Because of the exceptionally high number of food web compartments in this study, the likelihood approach is too computationally demanding, and therefore the parsimony approach in combination with range estimation was used. The most parsimonious solution is defined as the flow vector $\mathbf{x}$ that has the smallest sum of squared flow values (Vézina \& Platt 1988). Additionally, by means of the range estimation procedure, the minimum and maximum values of each flow in the solution space were determined (Klepper \& Van de Kamer 1987). The freely available software package LIM (Soetaert \& van Oevelen 2008) was used to solve the LIMs in R accordingly (v.3.1.2) (R Development Core Team 2015).

\section{Network indices}

In order to compare the complex interactions between compartments for the different food webs, several network indices were calculated from the output of the parsimony approach: total system throughput ( $T$.., the sum of all flow magnitudes in a network), total number of links $\left(L_{\text {tot }}\right)$, the average link weight $\left(\bar{T}_{i j}\right)$, the connectance $(C)$ and the average mutual information index (AMI, the average amount of constraint placed upon an arbitrary flow anywhere in the network). The $\mathrm{R}$ package NetIndices (Kones et al. 2009) was used to calculate the network indices in $R$. A summary of the nomenclature and the equations is given in Table S3 in the Supplement at www.intres.com/articles/suppl/m552p047_supp.pdf, but for a detailed overview see Ulanowicz (2004) and Kones et al. (2009).

\section{RESULTS}

\section{Biomass data}

The mean $( \pm \mathrm{SE})$ total biomass in a Lanice conchilega reef area $\left(18969 \pm 3992 \mathrm{mmol} \mathrm{C} \mathrm{m}{ }^{-2}\right)$ was 2 orders of magnitude higher than the mean total biomass in a bare sand area $\left(180 \pm 56 \mathrm{mmol} \mathrm{C} \mathrm{m}^{-2}\right)$ (Table S1 in the Supplement). The macrofaunal biomass (mean $\pm \mathrm{SE}$ in the reef areas was largely dominated by suspension feeders (BMSM: $85 \pm 4 \%$, Boulogne: $82 \pm 13 \%$ ). Main suspension feeders in the BMSM included L. Conchilega $(37 \pm 1 \%)$ and the bivalve Cerastoderma edule (48 $\pm 4 \%$ ). The remaining compartments constituted $15 \pm 4 \%$ of the total macrofaunal biomass. In the Boulogne reefs, L. conchilega made up the majority of the macrofaunal biomass $(82 \pm 13 \%)$, which was further complemented with the predator Carcinus maenas $(17 \pm 13 \%)$. The remaining compartments constituted $2 \pm 1 \%$ of the total macrofaunal biomass. In the bare sand areas of the BMSM, carbon stocks were much more variable and highest for the bivalves Cerastoderma edule (33 $\pm 33 \%)$, Macoma balthica $(29 \pm 10 \%)$ and Tellina tenuis $(12 \pm 7 \%)$, and the polychaetes Arenicola marina $(8 \pm 8 \%)$ and Nephtys cirrosa $(6 \pm 0.3 \%)$. The remaining compartments accounted for $12 \pm 8 \%$ of the total biomass in the bare sand areas of the BMSM. Carbon stocks in the bare sand areas of Boulogne were dominated by Carcinus maenas (48 $\pm 42 \%)$ and $N$. cirrosa $(33 \pm 26 \%)$. The remaining compartments accounted for $19 \pm 16 \%$ of the total biomass.

\section{Food web structure and model output}

Macrofaunal species richness (total number of compartments) was higher in reef areas (32 \pm 4 species) as compared to bare sand areas ( $24 \pm 4$ species). Differences in the food web structure become apparent when the carbon flows are plotted in a circular fashion (Fig. 3, Figs. S1-S3 in the Supplement at www.int-res.com/articles/suppl/m552p047_supp.pdf). The main difference between reef and bare sand food webs was the important role of $L$. conchilega in the reef areas, mainly complemented by the compartments of the bivalve Cerastoderma edule in the food webs of the BMSM, while Carcinus maenas had a prominent role in the food webs of Boulogne. In the bare sand areas, the mean $( \pm \mathrm{SE})$ total carbon ingested by the macrofaunal community was $5 \pm$ $2 \mathrm{mmol} \mathrm{C} \mathrm{m} \mathrm{C}^{-1}$ and was partitioned among the sources as $19 \pm 5 \%$ in situ produced phytoplankton, 
$58 \pm 13 \%$ microphytobenthos and $24 \pm 13 \%$ external phytoplankton (Table 2). In the reef areas, mean total carbon ingested by the macrofaunal community was much higher $\left(191 \pm 50 \mathrm{mmol} \mathrm{C} \mathrm{m} \mathrm{C}^{-2} \mathrm{~d}^{-1}\right)$. Moreover, in contrast to bare sand areas, external phytoplankton accounted for $73 \pm 5 \%$ of the carbon uptake by macrofauna, while in situ produced phytoplankton $(7$ $\pm 2 \%)$ and microphytobenthos $(20 \pm 3 \%)$ were com- paratively less important (Table 2). The majority of the total organic carbon in the reef areas was consumed by L. conchilega and ranged between $37 \%$ in the BMSM in spring and $94 \%$ in Boulogne in spring. Only in the reef area of the BMSM during spring was a larger part of the organic carbon (51\%) ingested by C. edule. Notwithstanding the important carbon flow from primary food sources to L. conchilega, the car-
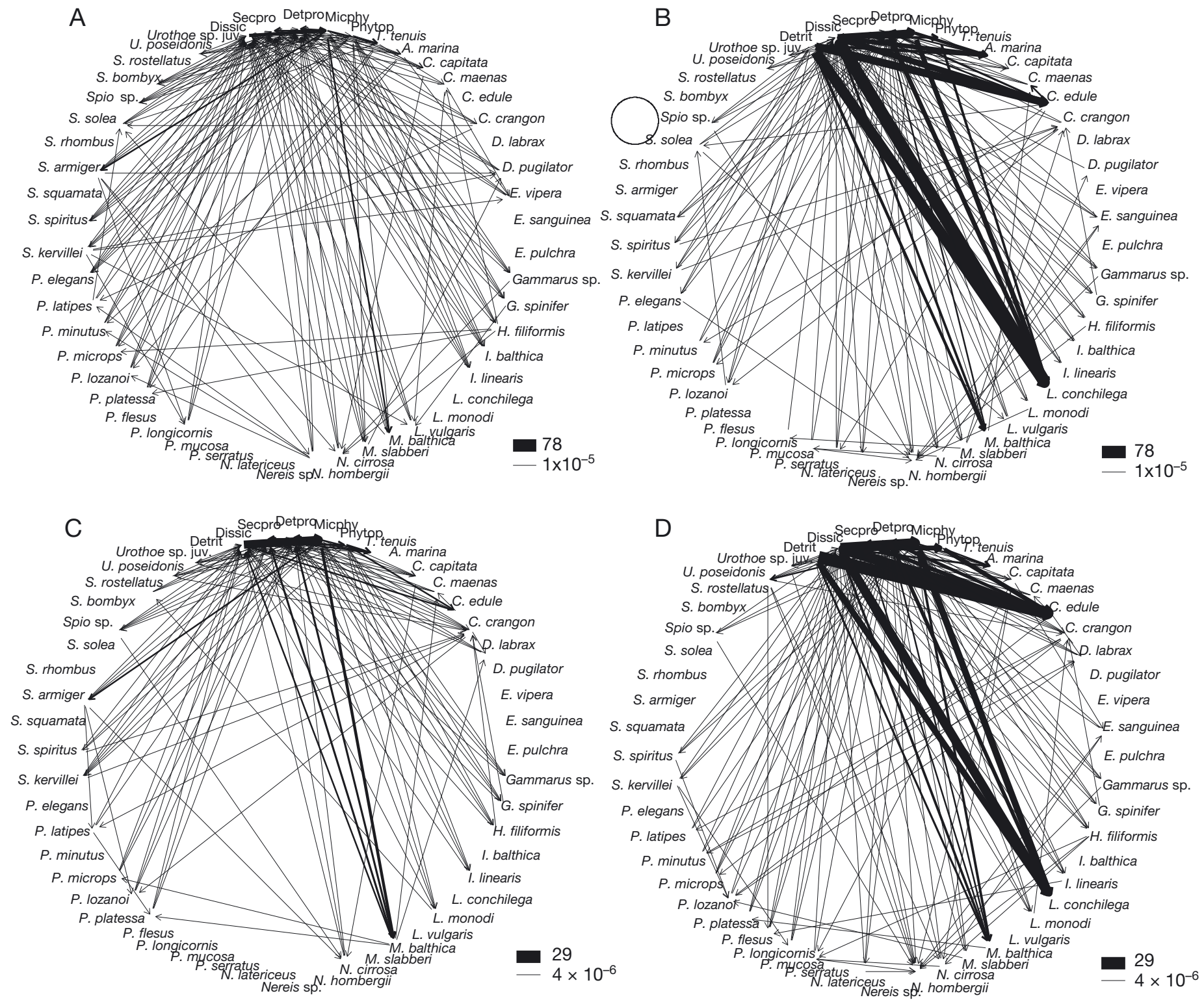

Fig. 3. Food web flows ( $\mathrm{mmol} \mathrm{C} \mathrm{m} \mathrm{C}^{-2}$ ) returned by the linear inverse food web models for the soft-bottom intertidal area of the Bay of Mont Saint-Michel: (A) Bare sand, autumn; (B) reef, autumn; (C) bare sand, spring; (D) reef, spring. Note the different magnitudes of the plotted flows between seasons: $(A, B)$ autumn: $1 \times 10^{-5}$ to $78 \mathrm{mmol} \mathrm{C} \mathrm{m}^{-2} \mathrm{~d}^{-1}$; (C,D) spring: $4 \times 10^{-6}$ to $29 \mathrm{mmol} \mathrm{C} \mathrm{m} \mathrm{d}^{-2} \mathrm{~d}^{-1}$. Circular flows indicate cannibalism. See Tables S1 \& S2 in the Supplement at www.int-res.com/ articles/suppl/m552p047_supp.pdf for full names of the food web compartments. Phytop = phytoplankton; micphy = microphytobenthos; detpro = external outflow to detritus; Detrit $=$ external inflow of organic matter; Dissic $=$ dissolved inorganic carbon; Secpro $=$ external outflow of secondary production. Minimum and maximum values as well as the parsimonious solution of the most important food web flows are given in Fig. S2 in the Supplement 
Table 2. Total ingested carbon $\left(\mathrm{mmol} \mathrm{C} \mathrm{m} \mathrm{m}^{-2} \mathrm{~d}^{-1}\right)$ and its partitioning $(\%$, in parentheses) among primary food sources for the different models of food webs of the Bay of Mont Saint-Michel (BMSM) and Boulogne for spring and autumn

\begin{tabular}{|c|c|c|c|c|c|c|c|c|}
\hline & \multicolumn{4}{|c|}{$\longrightarrow$ BMSM $\longrightarrow$} & \multicolumn{4}{|c|}{$\longrightarrow$ Boulogne $\longrightarrow$} \\
\hline & \multicolumn{2}{|c|}{-Autumn- } & \multicolumn{2}{|c|}{$\longrightarrow$ Spring -} & \multicolumn{2}{|c|}{-Autumn -} & \multicolumn{2}{|c|}{ - Spring } \\
\hline & Control & Reef & Control & Reef & Control & Reef & Control & Reef \\
\hline In situ phytoplankton & $1.4(18)$ & $9.5(5)$ & $2.2(27)$ & $9.5(13)$ & $0.04(6)$ & $9.5(3)$ & $0.5(24)$ & $9.5(5)$ \\
\hline Microphytobenthos & $6.5(82)$ & $36.6(20)$ & $5.7(70)$ & $18.6(26)$ & $0.4(58)$ & $38.0(12)$ & $0.4(22)$ & $43.7(23)$ \\
\hline External phytoplankton & $0.0(0)$ & $138.4(75)$ & $0.3(3)$ & $44.6(61)$ & $0.3(36)$ & $270.6(85)$ & $1.1(55)$ & $136.8(72)$ \\
\hline Total carbon ingested & 7.9 & 184.4 & 8.2 & 72.7 & 0.7 & 319.1 & 1.9 & 190.0 \\
\hline
\end{tabular}

bon throughput from the tubeworm to other macrofaunal compartments equalled zero for all reef food webs. The total respiration of the bare sand community was $6 \pm 2 \mathrm{mmol} \mathrm{C} \mathrm{m}^{-2} \mathrm{~d}^{-1}$ in the BMSM and $6 \pm$ $3 \mathrm{mmol} \mathrm{C} \mathrm{m}{ }^{-2} \mathrm{~d}^{-1}$ in Boulogne. Total respiration of the reef community was estimated to be $99 \pm 46 \mathrm{mmol} \mathrm{C}$ $\mathrm{m}^{-2} \mathrm{~d}^{-1}$ in the BMSM, and $193 \pm 48 \mathrm{mmol} \mathrm{C} \mathrm{m}^{-2} \mathrm{~d}^{-1}$ in Boulogne. L. conchilega performed $46 \pm 7 \%$ of the total respiration in the BMSM reef and $89 \pm 5 \%$ in the reef of Boulogne. Faeces production was $10 \pm 1 \mathrm{mmol}$ $\mathrm{C} \mathrm{m}^{-2} \mathrm{~d}^{-1}$ in the bare sand area of the BMSM and $8 \pm$ $0.2 \mathrm{mmol} \mathrm{C} \mathrm{m}^{-2} \mathrm{~d}^{-1}$ in the bare sand area of Boulogne, and $26 \pm 11 \mathrm{mmol} \mathrm{C} \mathrm{m} \mathrm{C}^{-1}$ in the reef area of the BMSM and $61 \pm 17 \mathrm{mmol} \mathrm{C} \mathrm{m}^{-2} \mathrm{~d}^{-1}$ in the reef area of Boulogne.

\section{Network indices}

$T . ., L_{\text {tot, }} C, \bar{T}_{i j}$, and AMI were calculated for the 8 different food webs (Table 3). The mean T.. ( \pm range) was considerably higher in an $L$. conchilega reef food web compared to a bare sand food web, both for the BMSM (reef: $305 \pm 118 \mathrm{mmol} \mathrm{C} \mathrm{m}{ }^{-2} \mathrm{~d}^{-1}$; bare sand: $59 \pm 5 \mathrm{mmol} \mathrm{C} \mathrm{m}^{-2} \mathrm{~d}^{-1}$ ) and Boulogne (reef: $578 \pm$ $136 \mathrm{mmol} \mathrm{C} \mathrm{m}^{-2} \mathrm{~d}^{-1}$; bare sand: $49 \pm 7 \mathrm{mmol} \mathrm{C} \mathrm{m}^{-2}$ $\left.\mathrm{d}^{-1}\right)$, although $L_{\text {tot }}$ was virtually the same in the bare sand $(137 \pm 20)$ and reef $(135 \pm 6)$ food webs of the BMSM, but conspicuously higher in the reef $(121 \pm 23)$ compared to the bare sand $(79 \pm 4)$ food webs of Boulogne. In both locations, the mean $C$ in a bare sand food web (BMSM: $0.068 \pm 0.006$; Boulogne: $0.099 \pm 0.026$ ) exceeded the mean $C$ in a reef food web (BMSM: $0.039 \pm 0.012$; Boulogne: $0.039 \pm 0.005)$. Dividing $T$.. by the number of links $(L)$ gives $\bar{T}_{i j}$, which was considerably higher in a reef food web compared to a bare sand food web but it was lower for the
BMSM (reef: $2.31 \pm 0.98$; bare sand: $0.44 \pm 0.10$ ) compared to Boulogne (reef: $4.73 \pm 0.23$; bare sand: 0.62 \pm 0.11 ). The mean AMI was higher in a reef food web versus a bare sand food web, both in the BMSM (reef: $1.59 \pm 0.07$; bare sand: $1.19 \pm 0.02$ ) and Boulogne (reef: $1.43 \pm 0.07$; bare sand: $1.13 \pm 0.06$ ).

\section{DISCUSSION}

Biogenic reefs created by Lanice conchilega are prominent habitats in soft-bottom intertidal areas. Recent studies have produced comprehensive data on the physical and biological characteristics of such reefs (e.g. see Rabaut et al. 2009 for an overview), but studies related to the associated reef food webs are scarce and non-quantitative (De Smet et al. 2015b). This study provides the first quantification of the carbon flows in a food web dominated by an ecosystem-engineered L. conchilega reef and in an adjacent site without a reef. Network analysis facilitated the comparison of the complex food web interactions, so that the influence of the specific characteristics of an $L$. conchilega reef on the structure and functioning of a soft-bottom intertidal food web could be identified.

Table 3. Overview of the calculated network indices for the reef and bare sand food webs of the Bay of Mont Saint-Michel (BMSM) and Boulogne for spring and autumn, based on the parsimony approach. T.. = total system throughput $\left(\mathrm{mmol} \mathrm{C} \mathrm{m} \mathrm{d}^{-2}\right), L_{\text {tot }}=$ total number of links, $C=$ connectance, $\bar{T}_{i j}=$ average link weight, and AMI = average mutual information

\begin{tabular}{|c|c|c|c|c|c|c|c|c|}
\hline & \multicolumn{4}{|c|}{$-\mathrm{BMSM}-$} & \multicolumn{4}{|c|}{ - Boulogne- } \\
\hline & \multicolumn{2}{|c|}{ Autumn } & \multicolumn{2}{|c|}{ Spring } & \multicolumn{2}{|c|}{ Autumn } & \multicolumn{2}{|c|}{ Spring } \\
\hline & Control & Reef & Control & Reef & Control & Reef & Control & Reef \\
\hline$T$.. & 53 & 423 & 64 & 187 & 42 & 714 & 55 & 441 \\
\hline$L_{\text {tot }}$ & 156 & 129 & 117 & 141 & 82 & 144 & 75 & 98 \\
\hline$C$ & 0.063 & 0.026 & 0.074 & 0.051 & 0.074 & 0.034 & 0.125 & 0.045 \\
\hline $\bar{T}_{i j}$ & 0.34 & 3.28 & 0.55 & 1.33 & 0.51 & 4.96 & 0.74 & 4.50 \\
\hline AMI & 1.17 & 1.52 & 1.21 & 1.66 & 1.07 & 1.36 & 1.20 & 1.50 \\
\hline
\end{tabular}




\section{Data quality and the food web model}

Most studies on inverse models make use of conventional size-based compartmentalization and feeding types to define the food web compartments. Additionally, many large and diverse groups (e.g. fishes) tend to be lumped into one box, masking details about specific interactions. The uniqueness of this study lies in its exceptionally high resolution: 48 single-species compartments were included in the model (Fig. 3; Tables S1 \& S2, Fig. S1 in the Supplement). The species compartments were selected out of all species occurring in the areas based on their abundance and biomass in the system (De Smet et al. 2015a). Due to a lack of data on meiofaunal and detrital compartments, the focus of this model therefore lies on the macrofaunal component of the L. conchilega reef and bare sand food webs. The developed food web model used a combination of site-specific biomass and stable isotope data, and empirical data and physiological constraints from the literature. Most of the 8 food web models could not be solved when the organic matter (OM) input per $\mathrm{m}^{2}$ to the sediment comprised only the in situ primary production per $\mathrm{m}^{2}$ (i.e. in situ phytoplankton and microphytobenthos). The in situ primary production rates are expressed per surface area, and do not take into account the continuous water flow over the reefs. In order to allow for an additional 'off-reef' OM input, an input of OM was added to the model and was termed external phytoplankton [DETRIT]. The quantity of this external OM input was left to be determined by the model.

\section{Carbon flows in Lanice conchilega reef areas}

The total input of carbon required to sustain the L. conchilega reef was high (mean \pm SE: $191 \pm$ $50 \mathrm{mmol} \mathrm{C} \mathrm{m} \mathrm{d}^{-2} \mathrm{~d}^{-1}$ ), whereas the in situ production was ca. 10 and $40 \mathrm{mmol} \mathrm{C} \mathrm{m} \mathrm{C}^{-2}$ in phytoplankton and microphytobenthos, respectively. This indicates that L. conchilega and its associated macrofaunal community fulfill their carbon requirement by extracting OM from a much larger volume of water than merely the overlying water column. In order to bridge the gap, $1 \mathrm{~m}^{2}$ of $L$. conchilega reef derives its energy from at least $15 \mathrm{~m}^{2}$ of overlying water column. The combined input of in situ produced and laterally advected external phytoplankton fuels most of the carbon input to the reef $(80 \pm 3 \%$ of the total $\mathrm{C}$ input), supporting the high biomass of suspension feeders $(83 \pm 6 \%$ of the total biomass in a reef) such as the bivalve Cerastoderma edule $(24 \pm 14 \%$ of the total biomass) and L. conchilega itself $(59 \pm 14 \%$ of the total biomass). Although L. conchilega is a surface deposit feeder, this species has the ability to switch to suspension feeding (Buhr 1976, Fauchald \& Jumars 1979). This is particularly advantageous to avoid competition in densely populated reef habitats (Buhr \& Winter 1977), such as the reefs modelled in the present study. The development of different particle capture and selection strategies reduces the competition between suspension feeders (Lefebvre et al. 2009) and might explain the co-occurrence of high abundances of $L$. conchilega and the suspension feeding bivalve $C$. edule in the BMSM reef.

The strong bentho-pelagic coupling in the L. conchilega reefs can be attributed to the trapping function of the reef habitat created by the tube-building polychaete (Fig. 4). Dense L. Conchilega aggregations facilitate the deposition of particulate matter by changing the hydrodynamics on small geographical scales (Friedrichs et al. 2000, Rabaut et al. 2007, Borsje et al. 2014), more specifically by decreasing the flow velocity at the sediment-water interface via a so-called skimming flow (Luckenbach 1986). Model results show that for low population densities, the flow velocities within an $L$. conchilega patch are strongly reduced, and hence particle deposition was enhanced (Borsje et al. 2014). Via a positive feedback loop, the effects caused by low-density reefs may result in an increasing population density, which on its turn enhances the particle deposition (Borsje et al. 2014). Besides the physical and passive trapping function of the reef, it can be expected that the high density reefs facilitate the bentho-pelagic coupling by the active suspension feeding activity of $L$. conchilega (and other macrofauna such as the bivalve $C$. edule) and the resulting production of (pseudo)faeces. For instance, the suspension-feeding anthozoan Sagartia troglodytes benefits from the high density of L. conchilega in the Weser estuary by taking up the faecal material expelled by the polychaete (Buhr \& Winter 1977). Nevertheless, the faeces produced within the reef areas equalled $30 \pm 2 \%$ of the additional 'off-reef' OM input, showing that even if all faeces produced within the reef areas were recycled by the macrofauna compartments, most of the carbon input in the L. conchilega food web would still result from the passive trapping function of the reef.

An increased food availability was already assumed for subtidal L. conchilega reef habitats (Van Hoey et al. 2008) and is now shown to also hold for the intertidal. Similar focussing of OM was, for instance, reported for deep reef structures created by 

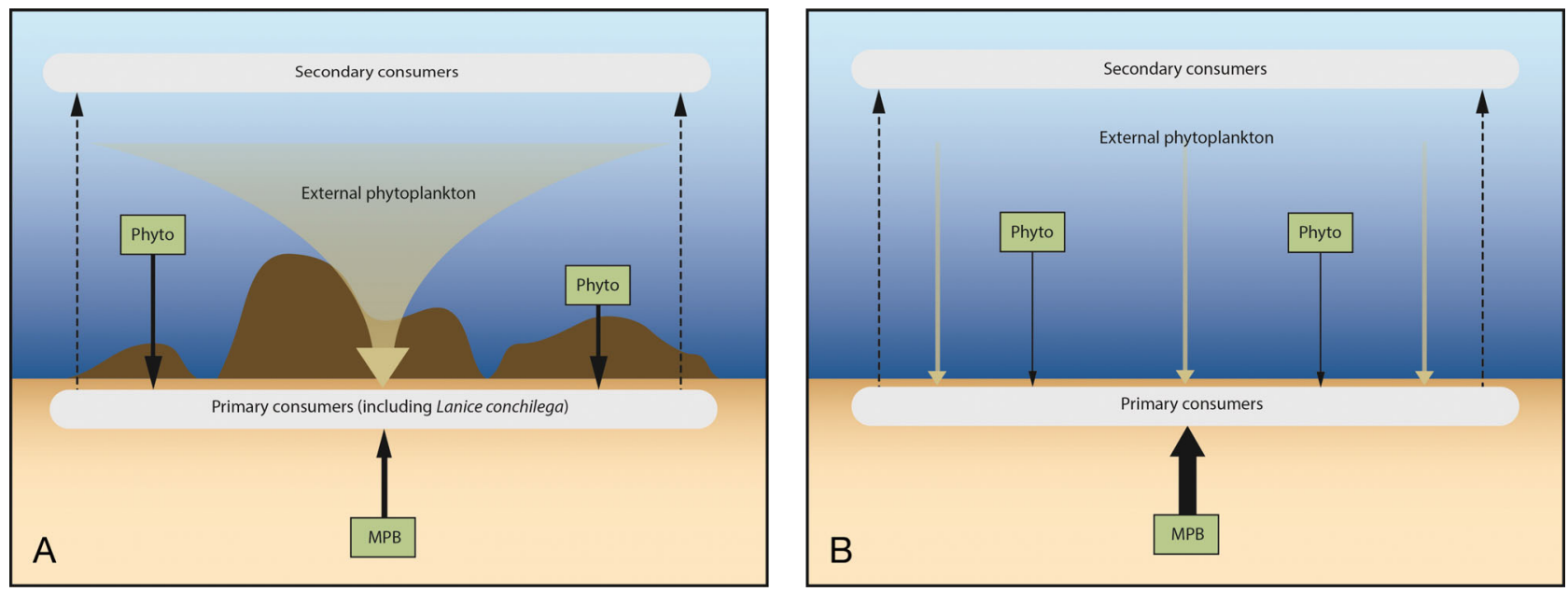

Fig. 4. Schematic representation of the important driving role of Lanice conchilega in the carbon flows (arrows) and dynamics in a soft-bottom intertidal food web. In the presence of the tubeworm (A) the water column-derived input of carbon (= in situ produced phytoplankton [Phyto] + external phytoplankton) prevails due to the trapping of organic matter by the reef structures (brown mounds). In a bare sand area (B) the carbon throughput is much lower and mainly dominated by the input of carbon from in situ primary production by MPB (microphytobenthos). Secondary consumers represent all organisms in the model which do not feed on phytoplankton or microphytobenthos. Arrow thickness represents the magnitude of the carbon flows

the cold-water coral Lophelia pertusa at $800 \mathrm{~m}$ depth at Rockall Bank (van Oevelen et al. 2009), and for mixed blue mussel Mytilus edulis and Pacific oyster Crassostrea gigas reefs in the intertidal flats of the Dutch Wadden Sea (van der Zee et al. 2012). In the latter bivalve reefs, the distribution of several macrobenthic species and shorebirds is strongly affected by the increase in sediment organic matter content, demonstrating that the bivalve reefs can affect consumer-resource interactions far beyond their own physical spatial boundaries in intertidal soft-sediment systems (van der Zee et al. 2012). Additionally, van der Zee et al. (2012) show that the presence of $L$. conchilega in the bio-engineered bivalve reefs locally enhances the engineering effect of the reefs on the benthic and shorebird community. In the present study, the intertidal $L$. conchilega reefs are similar to the bivalve reefs with respect to their largescale engineering affects. The facilitated OM trapping by the reefs and the consequential impacts on the macrobenthic community and the fish and wading bird populations (De Smet et al. 2013, 2015a) demonstrate that the spatial impact of $L$. conchilega reefs is much larger than their size suggests.

Notwithstanding the important carbon flow from primary food sources to $L$. conchilega, the direct carbon throughput from the tubeworm to other macrofaunal compartments in the reef equalled zero. This finding opposes observations showing that $L$. conchilega is a prey item for higher trophic levels such as (flat)fishes (Amara et al. 2001) and waders (GossCustard \& Jones 1976, Yates et al. 1993, De Smet et al. 2013). Therefore, the flows from the tubeworm to other organisms are probably underestimated by the model and by the parsimony approach to solve the model (Vézina \& Platt 1988). Nevertheless, the model outcome gives a good indication of the relatively limited role of $L$. conchilega in direct trophic interactions within the reef. Overall, the tubeworm creates the environmental conditions to sustain the food web, but itself represents a sink of carbon rather than an important conduit to sustain other macrofaunal organisms. The large biomass of suspension feeders not available for consumption within the system was previously assumed to explain the low transfer efficiency from primary producers to higher trophic levels in the BMSM (Arbach Leloup et al. 2008).

\section{Carbon flows in bare sand areas}

The total carbon input in a bare sand area is 2 orders of magnitude lower than in an L. conchilega reef area, resulting in a macrofaunal biomass which is 2 orders of magnitude lower in a bare sand area compared to a reef area. In the bare sand areas, the pelagic primary production suffices to sustain the OM requirements of the macrofaunal community. Moreover, only a small fraction of the in situ produced primary production in bare sand areas was 
consumed by the macrofaunal community. Also, the partitioning of the carbon input from the primary food sources to the macrofaunal community differs considerably in the bare sand areas. In comparison to the $L$. conchilega reef areas, the water columnderived fraction of the carbon input in bare sand areas is about half the amount of the water columnderived carbon input in the reef. In bare sand areas, the main supply of carbon is rather provided by the in situ production of microphytobenthos (Fig. 4).

\section{Network characteristics}

Network indices are a convenient way to represent certain aspects of food webs and to facilitate comparisons among them (Ulanowicz 2004, Kones et al. 2009). Although it is recommended to calculate network indices on the median values from the likelihood approach (Kones et al. 2009), in the present study, this was not feasible due to the large number of compartments in the inverse food web models. The use of the parsimony approach in this study typically provides low estimates of the network indices of the food webs (Kones et al. 2009). However, as all the food webs are based on the same overall topological food web structure with the same food web flows and units, the calculation of the network indices is consistent, justifying the comparison of the presented network indices between the food webs (Kones et al. 2009).

The high carbon flow in the reef food webs is reflected in the total system throughput index (T..), which sums carbon flows to obtain a measure of the total food web activity (Ulanowicz 2004) and which is 3 to 17 times higher in reef ecosystems compared to bare sand areas. The presence of $L$. conchilega not only increases the overall metabolic activity, it also entails a more diverse macrofaunal community, with 10 to $80 \%$ more compartments being present in the reefs. This is also reflected in the complexity of the food webs which can best be appraised by comparing the on- and off-reef webs (see Fig. 3, Fig. S1 in the Supplement), showing much more sparsely connected food webs in bare sand sites. The AMI, which assesses the developmental status of an ecosystem and quantifies how orderly and coherently food web flows are connected, is indeed highest for reef areas, which is consistent with the stabilising effect of the ecosystem engineering activities of $L$. conchilega (Godet et al. 2009, Rabaut et al. 2009). The higher AMI values resulting from the stabilised conditions within the reef are in line with the AMI values meas- ured in the absence of resuspension of the microphytobenthic biofilm in the Bay of Marennes-Oléron (Saint-Béat et al. 2014).

\section{Location differences}

Although on- and off-reef food webs are, in general, qualitatively similar, there are nonetheless differences between the intertidal food webs in the 2 study locations. Reefs in Boulogne had a much higher L. conchilega biomass and therefore also higher total carbon flows (Table 3). Another consequence of the higher tubeworm biomass is the elevated carbon ingestion and respiration in the reef food web of Boulogne; despite the complete absence of the cockle $C$. edule in the sampling areas of Boulogne. Differences in $L$. conchilega density between the 2 locations was previously identified as the main driver of differences in the macro- and epifaunal community descriptors (e.g. species abundance and diversity) between reef and bare sand areas; being more pronounced in Boulogne (De Smet et al. 2015a). The low abundance and hence the minor role of the predator crab Carcinus maenas in the food webs of the BMSM is expected to be due to its preference for the food and shelter provided by shellfish farms in the low intertidal of the BMSM (Le Mao et al. 2004). In contrast, in Boulogne, shellfish farms are absent and C. maenas is mainly observed on the $L$. conchilega reef. Similarly, in the Bay of Veys (France), C. maenas was observed in sites dominated by oyster cultures and with a mean $( \pm \mathrm{SE})$ L. conchilega density of $1885.7 \pm$ 343.9 ind. $\mathrm{m}^{-2}$, whereas this predator was absent in adjacent sites without oyster cultures and an $L$. conchilega density of $1750.2 \pm 368.4$ ind. $\mathrm{m}^{-2}$ (Dubois et al. 2007).

\section{CONCLUSIONS}

The influence of large polychaete populations in shallow coastal areas is often underestimated and their ecological role in the coastal food web is not well known (Dubois et al. 2009). The use of linear inverse modelling in this study provides new insights into the functioning of an $L$. conchilega reef and its role in a soft-bottom intertidal food web. We show that the presence of biogenic reefs constructed by the ecosystem engineer $L$. conchilega focusses OM produced in an area at least one order of magnitude larger than the reef itself. The tubeworm reinforces the bentho-pelagic coupling by establishing reef 
structures which act as a trap of OM. As this also benefits other organisms, the resulting food web in the presence of the tubeworm is much more diverse. However, the worm has only a facilitating role; it does not constitute a significant source of carbon for other macrofaunal organisms. The effect of $L$. conchilega on the carbon dynamics in a reef food web seems to be applicable to locations with different environmental conditions, but can differ in magnitude depending on the density of the tubeworm reefs.

Acknowledgements. The authors thank N. Viane for his technical assistance in the lab. Funding was provided by the Special Research Fund (BOF-GOA 01GA1911W), Ghent University, Belgium and by the VIDI grant awarded to D.v.O. (864.13.007, NWO, The Netherlands).

\section{LITERATURE CITED}

Amara R, Laffargue P, Dewarumez JM, Maryniak C, Lagardere F, Luczac C (2001) Feeding ecology and growth of O-group flatfish (sole, dab and plaice) on a nursery ground (Southern Bight of the North Sea). J Fish Biol 58: 788-803

Arbach Leloup F, Desroy N, Le Mao P, Pauly D, Le Pape O (2008) Interactions between a natural food web, shellfish farming and exotic species: the case of the Bay of Mont Saint Michel (France). Estuar Coast Shelf Sci 76: 111-120

Banse K (1979) On weight dependence of net growth efficiency and specific respiration rates among field populations of invertebrates. Oecologia 38:111-126

Berlow EL, Neutel AM, Cohen JE, De Ruiter PC and others (2004) Interaction strengths in food webs: issues and opportunities. J Anim Ecol 73:585-598

Borsje BW, Bouma TJ, Rabaut M, Herman PMJ, Hulscher S (2014) Formation and erosion of biogeomorphological structures: a model study on the tube-building polychaete Lanice conchilega. Limnol Oceanogr 59:12971309

Braeckman U, Provoost P, Gribsholt B, Van Gansbeke D and others (2010) Role of macrofauna functional traits and density in biogeochemical fluxes and bioturbation. Mar Ecol Prog Ser 399:173-186

Braeckman U, Van Colen C, Soetaert K, Vincx M, Vanaverbeke J (2011) Contrasting macrobenthic activities differentially affect nematode density and diversity in a shallow subtidal marine sediment. Mar Ecol Prog Ser 422: 179-191

Brey $\mathrm{T}$ (2001) Population dynamics in benthic invertebrates. A virtual handbook. www.thomas-brey.de/science/ virtualhandbook

Buhr KJ (1976) Suspension-feeding and assimilation efficiency in Lanice conchilega (Polychaeta). Mar Biol 38: 373-383

- Buhr K, Winter J (1977) Distribution and maintenance of a Lanice conchilega association in the Weser estuary (FRG), with special reference to the suspension-feeding behaviour of Lanice conchilega. In: Keegan BF, Boaden PJS, Ceidigh PO (eds) Biology of benthic organisms.
Proc 11th Eur Symp Mar Biol, Galway, October 1976, p 101-113

Calow P (1977) Conversion efficiencies in heterotrophic organisms. Biol Rev Camb Philos Soc 52:385-409

Davoult D, Migné A, Créach A, Gevaert F, Hubas C, Spilmont N, Boucher G (2009) Spatio-temporal variability of intertidal benthic primary production and respiration in the western part of the Mont Saint-Michel Bay (Western English Channel, France). Hydrobiologia 620:163-172

$>$ De Ruiter PC, Neutel A-M, Moore JC (1995) Energetics, patterns of interaction strengths, and stability in real ecosystems. Science 269:1257-1260

> De Smet B, Godet L, Fournier J, Desroy N, Jaffré M, Vincx M, Rabaut M (2013) Feeding grounds for waders in the Bay of the Mont Saint-Michel (France): the Lanice conchilega reef serves as an oasis in the tidal flats. Mar Biol 160:751-761

De Smet B, D'Hondt AS, Verhelst P, Fournier J and others (2015a) Biogenic reefs affect multiple components of intertidal soft-bottom benthic assemblages: the Lanice conchilega case study. Estuar Coast Shelf Sci 152:44-55

$>$ De Smet B, Fournier J, De Troch M, Vincx M, Vanaverbeke $\mathrm{J}$ (2015b) Integrating ecosystem engineering and food web ecology: testing the effect of biogenic reefs on the food web of a soft-bottom intertidal area. PLoS ONE 10: e0140857

De Smet B, Braeckman U, Soetaert K, Vincx M, Vanaverbeke J (2016) Predator effects on the feeding and bioirrigation activity of ecosystem-engineered Lanice conchilega reefs. J Exp Mar Biol Ecol 475:31-37

> Degraer S, Moerkerke G, Rabaut M, Van Hoey G and others (2008) Very-high resolution side-scan sonar mapping of biogenic reefs of the tube-worm Lanice conchilega. Remote Sens Environ 112:3323-3328

> Dubois S, Marin-Leal JC, Ropert M, Lefebvre S (2007) Effects of oyster farming on macrofaunal assemblages associated with Lanice conchilega tubeworm populations: a trophic analysis using natural stable isotopes. Aquaculture 271:336-349

$>$ Dubois S, Barille L, Cognie B (2009) Feeding response of the polychaete Sabellaria alveolata (Sabellariidae) to changes in seston concentration. J Exp Mar Biol Ecol 376: 94-101

Fauchald K, Jumars PA (1979) The diet of worms: a study of polychaete feeding guilds. Oceanogr Mar Biol Annu Rev 17:193-284

Fenchel T (1982) Ecology of heterotrophic microflagellates. II. Bioenergetics and growth. Mar Ecol Prog Ser 8: 225-231

Forster S, Graf G (1995) Impact of irrigation on oxygen flux into the sediment: intermittent pumping by Callianassa subterranea and 'piston-pumping' by Lanice conchilega. Mar Biol 123:335-346

Friedrichs M, Graf G, Springer B (2000) Skimming flow induced over a simulated polychaete tube lawn at low population densities. Mar Ecol Prog Ser 192:219-228

Froese R, Pauly D (2015) FishBase. www.fishbase.org (accessed in February 2015)

Godet L, Toupoint N, Olivier F, Fournier J, Retière C (2008) Considering the functional value of common marine species as a conservation stake: the case of sandmason worm Lanice conchilega (Pallas 1766) (Annelida, Polychaeta) beds. Ambio 37:347-355

Godet L, Toupoint N, Fournier J, Le Mao P, Retiere C, Olivier F (2009) Clam farmers and oystercatchers: effects 
of the degradation of Lanice conchilega beds by shellfish farming on the spatial distribution of shorebirds. Mar Pollut Bull 58:589-595

Goss-Custard J, Jones R (1976) The diets of redshank and curlew. Bird Study 23:233-243

Hartmann-Schröder G (1996) Annelida, Borstenwürmer, Polychaeta. 2nd revised edn. The fauna of Germany and adjacent seas with their characteristics and ecology, 58. Gustav Fischer, Jena

> Hendriks AJ (1999) Allometric scaling of rate, age and density parameters in ecological models. Oikos 86:293-310

> Hepher B, Liao IC, Cheng SH, Hsieh CS (1983) Food utilization by red tilapia - effects of diet composition, feeding level and temperature on utilization efficiencies for maintenance and growth. Aquaculture 32:255-275

Holt T, Rees E, Hawkins S, Seed R (1998) Biogenic reefs. an overview of dynamic and sensitivity characteristics for conservation management of marine SAC. Scottish Association for Marine Science (UK Marine SACs Project)

Jobling M (1994) Fish bioenergetics. Chapman \& Hall, London

> Jones CG, Lawton JH, Shachak M (1994) Organisms as ecosystem engineers. Oikos 69:373-386

> Jordana E, Charles F, Grémare A, Amouroux JM, Chrétiennot-Dinet MJ (2001) Food sources, ingestion and absorption in the suspension-feeding polychaete, Ditrupa arietina (O.F. Müller). J Exp Mar Biol Ecol 266:219-236

> Klepper O, Van de Kamer J (1987) The use of mass balances to test and improve the estimates of carbon fluxes in an ecosystem. Math Biosci 85:37-49

Kones JK, Soetaert K, van Oevelen D, Owino JO (2009) Are network indices robust indicators of food web functioning? A Monte Carlo approach. Ecol Modell 220:370-382

Le Mao P, Retiere C, Le Bec C, Gerla D (2004) Gérer un anthroposystème littoral à forte valeur patrimoniale: Comment relever ce défi en baie du Mont-Saint-Michel? Institut océanographique, Paris

> Lefebvre S, Leal JCM, Dubois S, Orvain F and others (2009) Seasonal dynamics of trophic relationships among cooccurring suspension-feeders in two shellfish culture dominated ecosystems. Estuar Coast Shelf Sci 82: 415-425

> Luckenbach MW (1986) Sediment stability around animal tubes: the roles of hydrodynamic processes and biotic activity. Limnol Oceanogr 31:779-787

> Mahaut ML, Sibuet M, Shirayama Y (1995) Weight-dependent respiration rates in deep-sea organisms. Deep-Sea Res I 42:1575-1582

Nielsen AM, Eriksen NT, Iversen JJL, Riisgård HU (1995) Feeding, growth and respiration in the polychaetes Nereis diversicolor (facultative filter-feeder) and $N$. virens (omnivorous) - a comparative study. Mar Ecol Prog Ser 125:149-158

Pacella SR, Lebreton B, Richard P, Phillips D, DeWitt TH, Niquil N (2013) Incorporation of diet information derived from Bayesian stable isotope mixing models into massbalanced marine ecosystem models: a case study from the Marennes-Oléron Estuary, France. Ecol Modell 267: 127-137

Petersen B, Exo KM (1999) Predation of waders and gulls on Lanice conchilega tidal flats in the Wadden Sea. Mar Ecol Prog Ser 178:229-240

R Development Core Team (2015) R: a language and environment for statistical computing. R Foundation for Statistical Computing, Vienna
Rabaut M, Guilini K, Van Hoey G, Magda V, Degraer S (2007) A bio-engineered soft-bottom environment: the impact of Lanice conchilega on the benthic speciesspecific densities and community structure. Estuar Coast Shelf Sci 75:525-536

Rabaut M, Vincx M, Degraer S (2009) Do Lanice conchilega (sandmason) aggregations classify as reefs? Quantifying habitat modifying effects. Helgol Mar Res 63:37-46

> Rabaut M, Audfroid Calderón M, Van de Moortel L, van Dalfsen J, Vincx M, Degraer S, Desroy N (2013) The role of structuring benthos for juvenile flatfish. J Sea Res 84: $70-76$

Saint-Béat B, Dupuy C, Agogué H, Carpentier A and others (2014) How does the resuspension of the biofilm alter the functioning of the benthos-pelagos coupled food web of a bare mudflat in Marennes-Oléron Bay (NE Atlantic)? J Sea Res 92:144-157

> Schroeder LA (1981) Consumer growth efficiencies: their limits and relationships to ecological energetics. J Theor Biol 93:805-828

Soetaert K, van Oevelen D (2008) LIM: linear inverse model examples and solution methods. R Package Version 1.4. http://lib.stat.cmu.edu/R/CRAN/web/packages/LIM/ index.html

Soetaert K, van Oevelen D (2009) Modeling food web interactions in benthic deep-sea ecosystems: a practical guide. Oceanography (Wash DC) 22:128-143

> Stephens MP, Kadko DC, Smith CR, Latasa M (1997) Chlorophyll-a and pheopigments as tracers of labile organic carbon at the central equatorial Pacific seafloor. Geochim Cosmochim Acta 61:4605-4619

> Struski C, Bacher C (2006) Preliminary estimate of primary production by phytoplankton in Marennes-Oléron Bay, France. Estuar Coast Shelf Sci 66:323-334

> Ulanowicz RE (2004) Quantitative methods for ecological network analysis. Comput Biol Chem 28:321-339

> van der Zee EM, van der Heide T, Donadi S, Eklöf JS and others (2012) Spatially extended habitat modification by intertidal reef-building bivalves has implications for consumer-resource interactions. Ecosystems 15:664-673

> Van Hoey G, Vincx M, Degraer S (2006) Some recommendations for an accurate estimation of Lanice conchilega density based on tube counts. Helgol Mar Res 60: 317-321

> Van Hoey G, Guilini K, Rabaut M, Vincx M, Degraer S (2008) Ecological implications of the presence of the tube-building polychaete Lanice conchilega on softbottom benthic ecosystems. Mar Biol 154:1009-1019

van Oevelen D, Soetaert K, Middelburg JJ, Herman PM and others (2006) Carbon flows through a benthic food web: Integrating biomass, isotope and tracer data. J Mar Res 64:453-482

> van Oevelen D, Duineveld G, Lavaleye M, Mienis F, Soetaert K, Heip CHR (2009) The cold-water coral community as a hot spot for carbon cycling on continental margins: a food-web analysis from Rockall Bank (northeast Atlantic). Limnol Oceanogr 54:1829-1844

> van Oevelen D, Meersche K, Meysman FR, Soetaert K, Middelburg J, Vézina A (2010) Quantifying food web flows using linear inverse models. Ecosystems 13:32-45

> van Oevelen D, Soetaert K, Heip C (2012) Carbon flows in the benthic food web of the Porcupine Abyssal Plain: the (un)importance of labile detritus in supporting microbial and faunal carbon demands. Limnol Oceanogr 57: $645-664$ 
Vézina AF, Platt T (1988) Food web dynamics in the ocean. I. Best-estimates of flow networks using inverse methods. Mar Ecol Progr Ser 42:269-287

Woodward G, Speirs DC, Hildrew AG (2005) Quantification and resolution of a complex, size-structured food web. Adv Ecol Res 36:85-135

WoRMS Editorial Board (2015). World Register of Marine Species. www.marinespecies.org (accessed on 29 March 2015)

Editorial responsibility: Just Cebrian,

Dauphin Island, Alabama, USA
Yates M, Goss-Custard J, McGrorty S, Lakhani K and others (1993) Sediment characteristics, invertebrate densities and shorebird densities on the inner banks of the Wash. J Appl Ecol 30:599-614

Zühlke R, Blome D, Van Bernem KH, Dittmann S (1998) Effects of the tube-building polychaete Lanice conchilega (Pallas) on benthic macrofauna and nematodes in an intertidal sandflat. Senckenb Marit 29:131-138

Submitted: December 10, 2015; Accepted: April 24, 2016 Proofs received from author(s): June 6, 2016 